First Peoples Child \& Family Review

An Interdisciplinary Journal Honouring the Voices, Perspectives, and Knowledges of

First Peoples through Research, Critical Analyses, Stories, Standpoints and Media

Reviews

\title{
A New Beginning
}

\section{Raven Sinclair}

Volume 6, Number 1, 2011

URI: https://id.erudit.org/iderudit/1068893ar

DOI: https://doi.org/10.7202/1068893ar

See table of contents

Publisher(s)

First Nations Child and Family Caring Society of Canada

ISSN

1708-489X (print)

2293-6610 (digital)

Explore this journal

Cite this document

Sinclair, R. (2011). A New Beginning. First Peoples Child \& Family Review, 6(1),

9-9. https://doi.org/10.7202/1068893ar viewed online.

https://apropos.erudit.org/en/users/policy-on-use/ 


\title{
First Peoples Child \& Family Review
}

An Interdisciplinary Journal Honoring the Voices, Perspectives and Knowledges of First

Peoples through Research, Critical Analyses, Stories, Standpoints and Media Reviews

\section{Volume 6, Number 1, 2011, p. 9}

\section{A New Beginning}

\author{
Raven Sinclaira (C)2011 \\ a Associate Professor, Faculty of Social Work, University of Regina, SK.
}

My heart hangs on a willow in the East exposed to the scrutiny of the four winds revealing my grief to the four directions While I sit, heartless, in the arms of my lover and weep.

My heart dangles up high Red in the wind, twisting, turning to the morning, noon, and night.

Grandmothers gather 'round to inspect and nod, clucking knowingly.

Their love is a prayer not a release.

My heart is a stone that swings in a willow turning in the four winds crying out in the cold and dark weeping the pain and grief of a lifetime saving me from a cruel and untimely death that resembles a life of loss.

My heart is a stone,

A pebble in a red cloth bag

Bobbing high in a willow

Slowly turning to the 4 directions

in the light and the dark

A cold, frightened warrior

that pebble, that is my heart.

My heart was a stone

which I placed high in a willow

on the 2 nd last day of a long and short journey.

That cold, frightened warrior, she died peacefully in the night.

Today I shall reclaim her body for a tender return to Mother Earth.

Sealing a prayer and an offering for a new beginning and another life.

Questions or correspondence concerning this poem may be addressed directly to:

Raven Sinclair

Email: raven.sinclair@sasktel.net 